\title{
Economic Value of Ecosystem Disservices of Green Spaces found in Residential Plots of Dar es Salaam City
}

\author{
Nicholaus Mwageni ${ }^{1} \&$ Gabriel Kassenga ${ }^{1}$ \\ ${ }^{1}$ Department of Environmental Science and Management, Ardhi University, Dar es Salaam, Tanzania \\ Correspondence: Nicholaus Mwageni, Department of Environmental Science and Management, Ardhi University, \\ Dar es Salaam, Tanzania. Tel: 255-7-1279-0905. E-mail: nicholausmwageni2012@gmail.com
}

Received: June 17, 2021

doi:10.5539/jsd.v14n4p78
Accepted: July 8, $2021 \quad$ Online Published: July 8, 2021

URL: https://doi.org/10.5539/jsd.v14n4p78

\begin{abstract}
Most studies have reported benefits of green spaces to households but few studies have been reported on negative effects (disservices) as well as their economic cost. Understanding ecosystem disservices from home greenery is important for health, safety and security of urban environment. The current paper reports on a study on economic value of green spaces including aesthetics, health, safety and security, physical, social and economic disservices. The study employed focus group discussion and in-depth interviews using structured questionnaire. Results indicate that, $65 \%$ of the respondents face the aforementioned disservices. Disservices which are aesthetic in nature were found to be faced by majority followed by health and physical disservices. The study has shown that households spend an average of TZS 60,691 (USD 26) per year on prevention and control of aesthetic and health disservices. In totality, valuation of ecosystem disservices from home greeneries has revealed that a household can incur an average total cost of TZS 116,817 (USD 50) per year. At City level, the total disservice cost is estimated to be TZS 106 billion (USD 45,415,595) per year. Disservices affect 5\% of the annual household income on preventing and controlling their impacts. The study recommends that departments responsible for handling environmental management issues should recognize the value of green space and integrate aesthetic factors into their planning and budgeting.
\end{abstract}

Keywords: ecosystem disservices, valuation, prevention cost, control cost

\section{Introduction}

Green spaces are all evapotranspiring surfaces whose infiltration capacity is not compromised by natural and artificial factors. They include vegetated areas (urban parks, street trees, vegetable gardens, lawns and shrubs), water surfaces (wetlands, ponds, rivers, streams and oceans/sea) and unsealed and permeable surfaces (open spaces, playing grounds and football pitches) (Bolund \& Hunhammar, 1999; Campbell, 2001; La Greca et al., 2011; Mensah, 2014; Mng'ong'o, 2005). Green spaces provide various benefits which are referred to as ecosystem services. Apart from that there are negative impacts which are associated with green spaces and are called ecosystem disservices (Lyytim, 2019).

There are wide variety of disservices which may be produced by green spaces depending on different factors, such as species composition, location of the green space in relation to built structures, the growth patterns and life phase, stress caused by external conditions and the intensity of maintenance activities (Speak, Escobedo, Russo, \& Zerbe, 2018). Green spaces have many disservices that impact on different aspects including human health notably allergic reactions (Cariñanos, Calaza-martínez, \& Brien, 2017). Also green spaces provide habitats for pests and disease vectors, biogenic volatile organic compounds and secondary aerosol emissions from trees, carbon and methane emissions from decomposition affecting air quality, economic issues, mobility and infrastructure issues (Vaz et al., 2017).

The most significant ecosystem disservices in urban areas are caused by species invasion. Although they may constitute natural processes, they can be mitigated or exacerbated through management (Wang, Qureshi, Knapp, Ross, \& Hubacek, 2015). Lack of attention to these ecosystem disservices may seriously hamper environmental management in general and urban green management in particular. Knowing ecological, social and technological changes will affect both what kind of disservices will emerge and how they will be experienced and managed (Dobbs, Escobedo, Clerici, Barrera, \& Eleuterio, 2019). 
The assessment of disservices is complicated because the same ecosystem function can be valued as a service or disservice depending on the person conducting the valuation and the context. For example, there are some species of trees which, one party may consider to be aesthetically pleasing, comforting and create a good shade while for another party the same tree species may be a source of allergens, leaf litter, and obstruction of view. These contrasting perceptions will depend not only on the structure of urban green spaces but also on the preferences of individuals and the specific pollution problem that degrade the quality of life (Oro, Ibbons, \& Elini, 2012).

The bad aspects of green spaces are known but the economic cost of the same is not known in most of urban areas (Campagne et al., 2018). This study aimed at assessing economic value of ecosystem disservices from green spaces found in residential areas of Dar es Salaam City. Results of the study are expected to help communities and decision makers to understand costs associated with the specific types of ecosystem disservices from green spaces found in urban areas. The results may be used to inform the planning and priority-setting among environmental quality management alternatives, with outcomes of supporting decision making on green space management at city level and place of domicile.

\section{Methodology}

\subsection{Selection of Case Study Area}

Other cities in Tanzania were considered during the choice of case study area and Dar es Salaam was found to be the most appropriate City since it has the highest urbanisation rate exacerbated by high population growth rate and density in Tanzania mainland. The increase in population in Dar es Salaam City has been contributed by natural growth by $83 \%$ and immigration by $17 \%$ (Lupala and Kiunsi, 2011) thus leading to higher conversion rate of green spaces to residential, commercial and industrial purposes than any other Cities in Tanzania (Kibassa and Shemdoe, 2016). As the result, Dar es Salaam City likely experiences most impacts caused by the absence of green spaces compared to other urban centres in Tanzania including heat stress, floods (storm water problem) and disappearance of recreational services. These challenges have created business opportunities for owners and suppliers of home greeneries. Residents are motivated to buy and plant greeneries in their residential plots with little knowledge on ecosystem disservices associated with types of green spaces to be established. Under climate change scenarios, green space interventions to mitigate against Climate Change impacts are likely to increase in the City. Thus, Dar es Salaam City has been chosen to study the economic value of green space ecosystem disservices.

Dar es Salaam is a coastal City with (5) Districts (Ilala, Temeke, Kinondoni, Kigamboni and Ubungo) comprising of ninety (90) wards (Figure 1). The current study was conducted in four (4) wards which were carefully selected to represent the Dar es Salaam City situation. The wards which were found to be predominantly residential were chosen using remote sensing techniques and GIS, in which 82 wards out of 90 wards were found to meet the requirements for the study. The approach was found not feasible due to costs implications and hence the eightytwo (82) wards were further screened using remote sensing techniques and GIS and all wards with all main green space types (vegetation, rivers and open spaces) were selected. Sixty (60) wards out of 82 wards were chosen, however, the number of wards was still high to be able to undertake the study considering limited resources available. The selected 60 wards were then assessed in terms of green space abundances using counting of buildings and population densities criteria implying that areas with high building density are expected to have low green space coverage and vice versa. Similarly, population density has implication on the extent of exposure to ecosystem disservices. The assessment came up with four classes of wards in which in each class one ward was chosen (Table 1). 
Table 1. Sampled wards

\begin{tabular}{|c|c|c|}
\hline Category & Sample ward & $\begin{array}{l}\text { Other wards in the category represented by } \\
\text { sample ward }\end{array}$ \\
\hline $\begin{array}{l}\text { Clase one- very high population and } \\
\text { housing density }\end{array}$ & Makumbusho & Makurumla, Tandale and Manzese \\
\hline $\begin{array}{l}\text { Class Two- high population and } \\
\text { housing density }\end{array}$ & Mburahati & Ndugumbi, Kigogo and Azimio \\
\hline $\begin{array}{l}\text { Class Three- moderate population } \\
\text { and housing density }\end{array}$ & Yombo Vituka & $\begin{array}{l}\text { Vingunguti, Mwananyamala, Magomeni, Mzimuni, } \\
\text { Charambe, Mchikichini, Tabata, Sandali, Kiwalani, } \\
\text { Sinza, Kijitonyama, Mbagala, Mtoni, Ilala }\end{array}$ \\
\hline $\begin{array}{l}\text { Class Four- low population and } \\
\text { housing density }\end{array}$ & Kawe & $\begin{array}{l}\text { Kinondoni, Ukonga, Kimanga,Miburani, Temeke, } \\
\text { Makubuli, Gongo la mboto, Ubungo, Kigamboni, } \\
\text { Kipawa, Mbezi juu, Chang'ombe, Kimara, Kivule, } \\
\text { Kitunda, Chamazi, Vijibweni, Upanga Magharibi, } \\
\text { Saranga, Mikocheni, Majohe, Pugu, Kinyerezi, } \\
\text { Makongo, Kibamaba, Chanika, Kunduchi, Goba, } \\
\text { Mbezi, Bunju, Msongola, Kwembe, Somangila, } \\
\text { Kimbiji, Kisarawe II, Pemba Mnazi }\end{array}$ \\
\hline
\end{tabular}

Wards within the class which were found to have similar characteristics of building and population density were differentiated by green space index. The green space indices were obtained by dividing the total area (coverage) of green space by total area of the ward. The total area of the ward was obtained from National Bureau of Statistics (NBS) of Tanzania. Green spaces coverage was obtained through on screen digitization using the same high resolution Dar es Salaam City ortho-rectified aerial imagery of 2017. Each green space chosen was digitized to get polygons. The areas were automatically generated by ArcGIS 10.3.1 software (ESRI, Redlands, California). In this regard, four settlements across Dar es Salaam City were chosen. In class one, Makumbusho was chosen as the case study area out of four wards, for class two, Mburahati was selected out of four wards, for class three, Yombo Vituka was picked out of 15 wards while for class four, Kawe was chosen out of 37 wards.

\subsection{Sampling of Households/Unit of Analysis}

The unit of analysis in the study was household. Households for the study were chosen by technique of purposive sampling. Based on Digital Elevation Model (DEM) all wards were sub-divided into a zone of high land (slope greater than 6) and low land (Slope lower than 6). The rationale for zoning was that the distribution and abundance of green spaces depends on the topographical nature of the area. The low land zone which is sometimes wetland in nature might have a good distribution and high abundance of green spaces than the high land due to differences in soil fertility and soil moisture if all factors are kept constant (Karaca et al., 2018). The division of settlements/wards into high and low land was achieved through development of digital elevation model (DEM) for each settlement/ward. In order to capture zoning and the whole concept of green spaces, the DEM was overlaid with green spaces map. Thereafter each zone (high land and low land) in the ward overlay map was further subdivided into blocks of $0.02 \mathrm{~km}^{2}$ and within which the most greenery house(s) were marked as the proposed households/respondents. The choice of households in both high land and low land zones considered their proximity to open spaces and streams for capturing the whole concept of green space, which may be vegetated land, stream or unsealed and permeable spaces (open space). A sample map in Figure 1 shows Yombo Vituka ward and its streets (mtaa) divided into high land zone, low land zone, streams and open spaces. Figure 1 also shows the green space distribution and the distribution of households. 


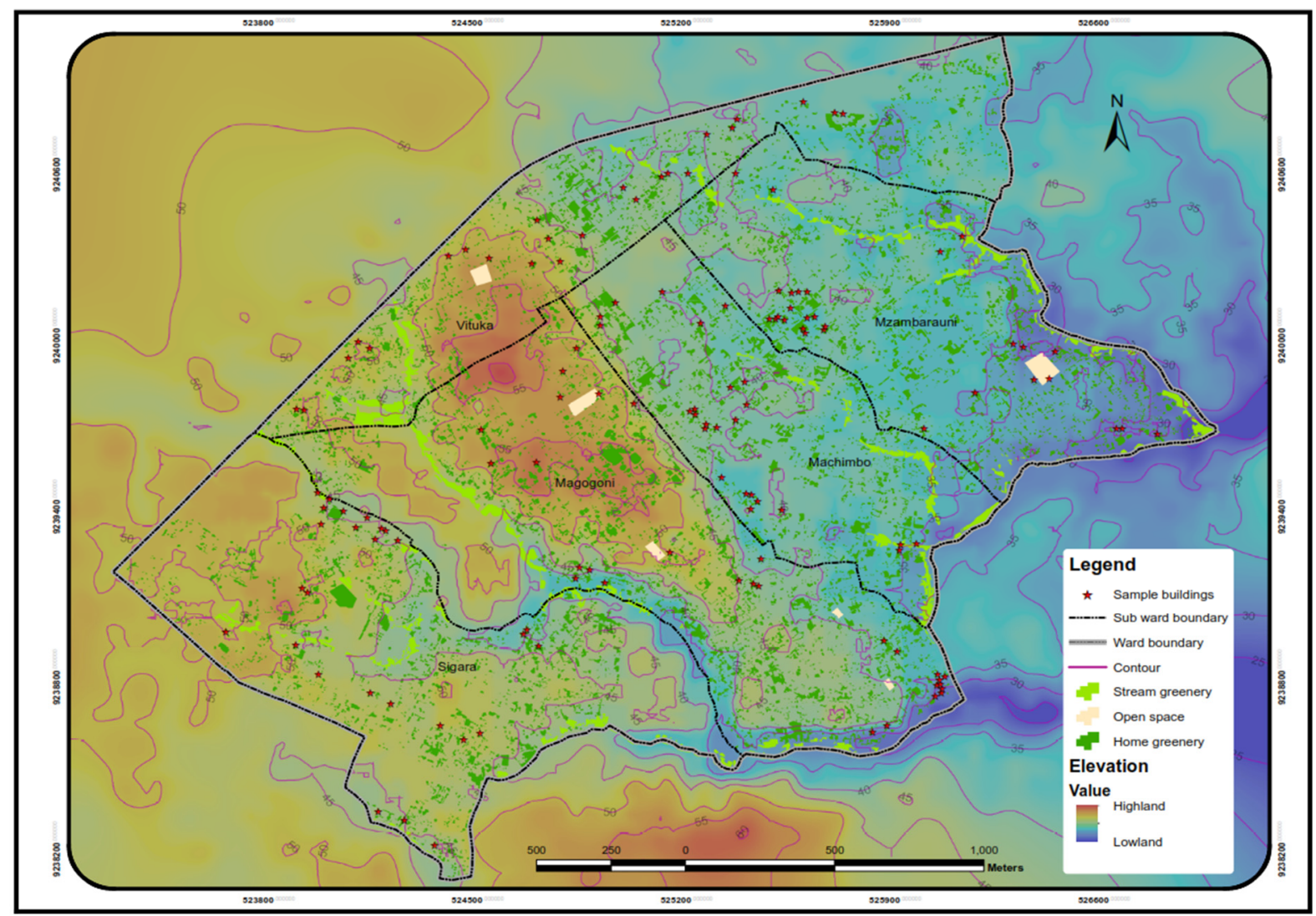

Figure 1. Distribution of samples according to topography and proximity to open spaces and stream in Yombo Vituka Ward

\subsection{Data Collection Methods}

\subsubsection{Focus Group Discussions}

This involved local authority officials and key informants within the settlements. The key informants were chosen on the basis of topographic nature of the case study and proximity to open spaces. Focus group discussion facilitated collection of information on settlement history as well as spatial distribution of green spaces and their disservices. Focus group constituted of 6 people whereby three (3) were female and three (3) were male.

Furthermore, disservices from each green space were discussed and ranked on the basis of their concern to participants who were considered to represent the settlement dwellers, opinions. Ecosystem disservices of major concern were given priority during valuation. To facilitate the discussion and assist the participants with visual tracks and clues of what has been discussed, the main points were noted down on wall mounted large papers in a tabular format. All disservices were listed first, and then each of the disservices were elaborated based on seven questions as follows: why they occur?; when do they get worse?; who is affected most?; what has been done to tackle them?; and, what should/could be done to tackle them? Moreover, new disservices were raised and added to the list as they were identified by participants.

The final task was for the participants to cast their votes one by one to determine the relative importance of the identified disservices for the case study area. Each participant was then given 10 match sticks as his/her total available votes, which he/she was required to cast on whichever ecosystem disservices he/she regards to be important to him/her. Then the majority opinion was considered to override the minority opinion.

\subsubsection{Household Questionnaire}

The essence of conducting household questionnaire within the settlement was firstly to triangulate the information collected during focus group discussion and secondly, to get deeper understanding of economic value of ecosystem disservices. The data obtained helped in establishing information on economic value of ecosystem disservices from green spaces in the case study areas. Questionnaires were structured after conducting focus group discussion. Thus, 
questions posed depended mainly on the pre-determined variables which can be used to determine the economic value (monetary loss) of ecosystem disservices from green spaces including prevention and control measures to aesthetic, health, physical and socio-economic related disservices (Table 2). Other information included demographic information, land tenure as well as its monetary effects on green spaces.

Table 2. Variables for determining monetary loss due to ecosystem disservices from green space

\begin{tabular}{ll}
\hline Monetary loss due to aesthetic related disservices \\
\hline Prevention cost & Quantity of treatment used for preventing the disservices (Units) \\
& Price per unit quantity of treatment used to prevent disservice(s)(TZS/units) \\
& Labor cost (if any)(TZS) \\
& Time spent per week(Hours) \\
& Value of time spent in preventing disservices (TZS/hour) \\
& Quantity of treatment for preventing the disservices (Units) \\
Control costs & Price per unit quantity (TZS) \\
& Labor cost if workforce is hired(TZS) \\
& Time spent per week(Hours) \\
& Value of time (TZS/hour)
\end{tabular}

\section{Monetary loss due to health related disservices}

Treatment cost if not using health insurance (TZS)

Treatment cost if using health insurance (TZS)

Location and transport cost(TZS)

Time taken for taking care of the patients and Travel time (Hours)

Value of time (TZS/Hour)

Distance to the ailment treatment location $(\mathrm{km})$

Fuel consumption rateif using private $\operatorname{car}(\mathrm{L} / \mathrm{km})$

Fuel price (TZS/L)

Cost of transport if using public transport (TZS)

Time spent to get treatment + time spent on the road (Hour)

Value of time(TZS/hour)

\section{Physical and Property Damage Cost}

Current recovery cost (TZS)

Possible recovery cost (TZS)

Expected labor cost if labour force is hired (TZS)

Time spent per week for household member if is in charge to recover physical and property damage (Hour)

Value of time (TZS/Hour)

\section{Social, Economic and Security Loss}

Medication cost (TZS)

Economic loss (TZS)

Property monetary loss (TZS)

The recovery cost (TZS)

Expected labor cost (TZS)

Time spent per week (Hour)

Value of time (TZS/Hour) 
Differences in socio-economic and environmental contexts of the City were captured by conducting the study in four different case studies. The actual questionnaire administration was preceded by a pre-test. This was done in Magomeni Suna and Mabwepande wards in which 50 questionnaires were administered to each ward. Based on challenges faced during a pre-test exercise, the questionnaire was updated/re-constructed. The questionnaire, which was updated on the basis of pre-test results was administered in four different settlements which had different, tenure types, socio-economic and environmental context (Table 2). In total, data collection was done involving 511 households within case study areas. The distribution of questionnaires/respondents in selected wards was based on the size of the ward and availability of residential houses with home greenery, streams and open spaces. The number of questionnaires administered in Makumbusho, Mbezi, Mburahati and Yombo Vituka wards was $127,150,100$ and 134, respectively. This was done by administering both closed and open- ended questions to households. Spatial distribution of case study settlements is shown in Figure 2.

Table 3. Key characteristics of case study settlements

\begin{tabular}{|c|c|c|c|c|}
\hline \multirow[t]{3}{*}{ Key information/source } & \multicolumn{4}{|c|}{ Sample Settlement } \\
\hline & \multirow[t]{2}{*}{ Kawe } & \multirow[t]{2}{*}{ Makumbusho } & \multirow[t]{2}{*}{ Mburahati } & \multirow{2}{*}{$\begin{array}{l}\text { Yombo } \\
\text { Vituka }\end{array}$} \\
\hline & & & & \\
\hline Population (NBS) & 67,115 & 68,093 & 34,123 & 76,999 \\
\hline Number of Household (NBS) & 16,778 & 18,403 & 9,749 & 19,249 \\
\hline Household size(NBS) & 4 & 3.7 & 3.9 & 4 \\
\hline Number of buildings as of 2017 & 7,962 & 6,591 & 3,445 & 9,342 \\
\hline Area of ward (Square kilometer) (NBS) & 15.477 & 1.113 & 1.7368 & 5.5453 \\
\hline Building density as of 2017 & 514 & 3794 & 3,095 & 1,684 \\
\hline $\begin{array}{l}\text { Modified Density type as per urban } \\
\text { planning space standards of Tanzania, } \\
2018\end{array}$ & $\begin{array}{l}\text { Super low } \\
\text { density }\end{array}$ & $\begin{array}{l}\text { Very } \\
\text { density }\end{array}$ & High density & $\begin{array}{l}\text { Medium } \\
\text { density }\end{array}$ \\
\hline $\begin{array}{l}\% \text { of planned and built } \\
\text { up area }\end{array}$ & 72.38 & 45.72 & 28.35 & 30.39 \\
\hline $\begin{array}{l}\% \text { of unplanned and } \\
\text { built up area }\end{array}$ & 9.64 & 54.28 & 71.65 & 60.05 \\
\hline$\%$ of un built up area & 17.98 & 0.0 & 0.0 & 9.55 \\
\hline Dominant type of buildings & $\begin{array}{l}\text { Double } \\
\text { storey }\end{array}$ & Single storey & Single storey & Single storey \\
\hline Green space coverage(square meter) & $6,627,540$ & 226,065 & 281,496 & $1,330,670$ \\
\hline Average slope & 2.4 & 2.1 & 2.5 & 2.73 \\
\hline
\end{tabular}




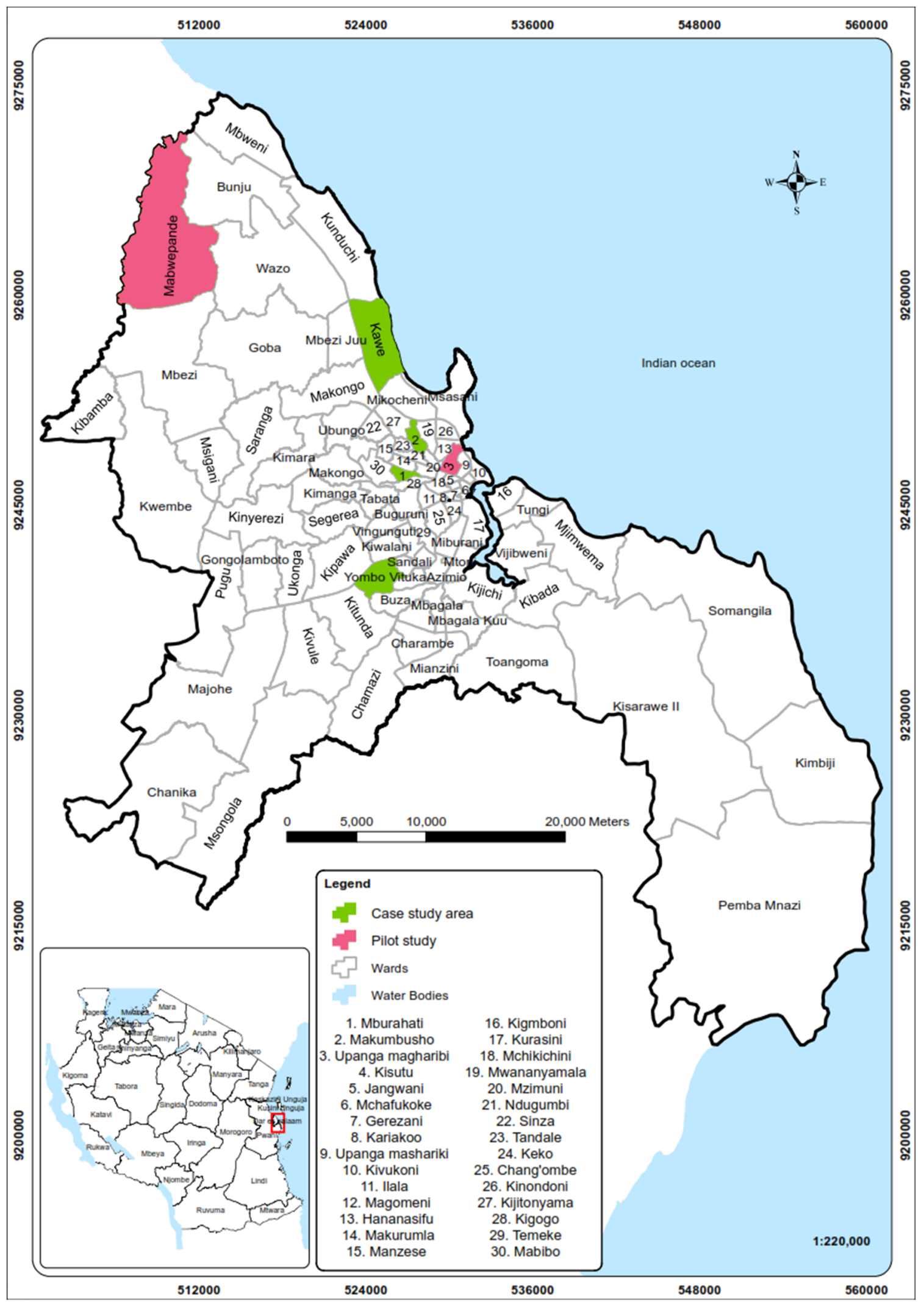

Figure 2. Location of study areas within Dar es Salaam 


\subsubsection{Quantification of Economic Value of Ecosystem Disservices}

The quantification of economic value of ecosystem disservices was done by a combination of various methods. These are opportunity cost (monetary sacrifice to gain the benefits from ecosystem services provision), travel cost (captures the travel time, travel cost), abatement cost/averting behaviour method (costs incurred to mitigate against impacts), and medication costs (accounting for all costs related to illness) (Table 3). The total economic value of ecosystem disservices (EVED) was determined as follows:

$$
\begin{aligned}
& \sum^{n}=\text { Monetary }+ \text { Monetary }+ \text { Monetary }+ \text { Monetary loss } \\
& \text { aesthetics healthy physical economic } \\
& \begin{array}{lllll}
\text { related related alated and } & \text { andion } 1
\end{array} \\
& \text { disservices disservices disservices related } \\
& \text { disservices } \\
& \begin{aligned}
\sum_{n=1}^{n} \text { EVED }= & \sum_{n=15}^{18} \mathrm{Cn}=\mathbf{C}_{\mathbf{1}}+\mathbf{C}_{2}+\mathbf{C}_{3}+\mathbf{C}_{4} \ldots \ldots \ldots \ldots \ldots \ldots . . . \ldots \text { Equation } 2 \\
=\quad & (\mathbf{A} \times \mathbf{D})+\mathbf{E}+(\mathbf{F} \times \mathbf{G})+(\mathrm{F} 4 \times \mathrm{G} 4)+\mathrm{H} 4+(\mathrm{I} 4 \times \mathrm{J} 4)+\mathrm{W} 2+\mathrm{X} 2+\mathrm{Y} 2+(\mathrm{Z} 2 \times \mathrm{A} 3)+ \\
& (\mathrm{B} 3 \times \mathrm{C} 3 \times \mathrm{D} 3)+\mathrm{F} 3+(\mathrm{I} 3 \times \mathrm{G} 3)+ \\
& \mathrm{K} 4+\mathrm{L} 4+\mathrm{M} 4+(\mathrm{N} 4 \times \mathrm{O} 4)+\mathrm{P} 4+\mathrm{Q} 4+\mathrm{R} 4+\mathrm{S} 4+\mathrm{T} 4+(\mathrm{U} 4 \times \mathrm{W} 4)
\end{aligned}
\end{aligned}
$$

Monetary loss as a result of ecosystem disservices due to physical damage particularly for variables K4, M4 and ( $\mathrm{N} 4 \mathrm{xO} 4)$ were adjusted for inflation using the following equation:

$$
A_{n}=A_{n-1}(1+r)
$$

Where,

$\mathrm{A}_{\mathrm{n}}=$ Equivalent monetary cost as of 2019

$\mathrm{A}_{\mathrm{n}-1}=$ Estimated monetary cost in the previous year

\begin{tabular}{|c|c|c|c|c|}
\hline \multicolumn{2}{|c|}{$\begin{array}{l}\text { Relevant variables for quantification of monetary loss due to } \\
\text { Ecosystem disservices }\end{array}$} & Symbol & $\begin{array}{l}\text { Adapted } \\
\text { Valuation } \\
\text { method }\end{array}$ & \multirow[t]{2}{*}{$\begin{array}{l}\text { Quantification } \\
\text { procedure }\end{array}$} \\
\hline \multicolumn{4}{|c|}{ Aesthetics disservices $\left(\mathrm{C}_{1}\right)$} & \\
\hline \multirow[t]{7}{*}{$\begin{array}{l}\text { Control } \\
\text { Costs }\end{array}$} & $\begin{array}{l}\text { Prevention mechanisms in place for the } \\
\text { disservices }\end{array}$ & $\mathbf{A}$ & $\begin{array}{l}\text { Averting } \\
\text { behavior }\end{array}$ & $(A \times \mathbf{D})+\mathbf{E}+(\mathbf{F} \times \mathbf{G})$ \\
\hline & $\begin{array}{l}\text { Quantity of treatment for preventing the } \\
\text { disservices (Units) }\end{array}$ & B & $(2007)$ & \\
\hline & Percentage of households affected by disservices & $\mathbf{C}$ & & \\
\hline & Price per unit quantity(TZS/units) & D & & \\
\hline & Labour cost (if any)(TZS) & $\mathbf{E}$ & & \\
\hline & Time spent per week (hours) & $\mathbf{F}$ & \multirow{2}{*}{$\begin{array}{l}\text { Opportunity } \\
\text { Cost(Ninan et al., } \\
\text { 2016) }\end{array}$} & \\
\hline & Value of time (TZS/hour) & $\mathbf{G}$ & & \\
\hline $\begin{array}{l}\text { Prevention } \\
\text { Costs }\end{array}$ & $\begin{array}{l}\text { Control mechanisms in place for the disservices } \\
\text { Quantity of treatment for controlling the } \\
\text { disservices you may need (units) }\end{array}$ & F4 & $\begin{array}{l}\text { Averting } \\
\text { behavior } \\
(2007)\end{array}$ & $\begin{array}{l}(\mathrm{F} 4 \times \mathrm{G} 4)+\mathrm{H} 4+(\mathrm{I} 4 \times \mathrm{J} \\
\text { 4) }\end{array}$ \\
\hline
\end{tabular}

$r=$ Country inflation data in the present year

Furthermore, the quantification of the monetary loss due to ecosystem disservices was based on assumption that opportunity cost of time for the respondent /household head represents the opportunity cost of time for the whole household since in household setting in the case study area it is the head of household who is required to provide all the needs of the family.

Table 4. Variables, adopted valuation method and quantification procedure 


\begin{tabular}{|c|c|c|c|}
\hline $\begin{array}{l}\text { Relevant variables for quantification of monetary loss due to } \\
\text { Ecosystem disservices }\end{array}$ & Symbol & $\begin{array}{l}\text { Adapted } \\
\text { Valuation } \\
\text { method }\end{array}$ & $\begin{array}{l}\text { Quantification } \\
\text { procedure }\end{array}$ \\
\hline Price per unit quantity (TZS/Units) & G4 & & \\
\hline Labour cost if workforce is hired (TZS) & H4 & & \\
\hline Time spent per week (Hour) & I4 & Opportunity & \\
\hline Value of time(TZS/hour) & $\mathbf{J} 4$ & $\begin{array}{l}\text { Cost(Ninan et al., } \\
\text { 2016) }\end{array}$ & \\
\hline \multicolumn{4}{|l|}{ Health disservices $\left(C_{2}\right)$} \\
\hline Treatment cost if not using health insurance(TZS) & W2 & \multirow{6}{*}{$\begin{array}{l}\text { Medication cost } \\
\text { (Pagiola et al., } \\
\text { 2004) } \\
\text { Opportunity cost } \\
\text { (Ninan et al., } \\
\text { 2016) }\end{array}$} & \multirow{13}{*}{$\begin{array}{l}\mathrm{W} 2+\mathrm{X} 2+\mathrm{Y} 2+(\mathrm{Z} 2 \times \mathrm{A} \\
3)+ \\
(\mathrm{B3} \times \mathrm{C3} \times \mathrm{D3})+\mathrm{F3}+(\mathrm{I} \\
3 \times \mathrm{G3})\end{array}$} \\
\hline Percentage of households affected by disservices & C & & \\
\hline Treatment cost if using health insurance (TZS) & $\mathbf{X} 2$ & & \\
\hline Who takes care of the patient? & & & \\
\hline Location and transport cost (TZS) & $\mathbf{Y} 2$ & & \\
\hline Time spent for taking care of the patient and Travel time(Hours) & $\mathbf{Z 2}$ & & \\
\hline Value of time (TZS/hour) & A3 & & \\
\hline Distance to the treatment point $(\mathrm{km})$ & B3 & \multirow{4}{*}{$\begin{array}{l}\begin{array}{l}\text { Travel } \\
\text { method }\end{array} \\
\text { (Pagiola et } \quad \text { cost } \\
2004)\end{array}$} & \\
\hline Fuel consumption rate $(\mathrm{L} / \mathrm{km})$ if using private car & $\mathbf{C 3}$ & & \\
\hline Fuel price $(\mathrm{TZS} / \mathrm{L})$ & D3 & & \\
\hline Cost of transport if using public transport (TZS) & F3 & & \\
\hline Time spent to get treatment + time spent on the road (Hour) & I3 & \multirow{2}{*}{$\begin{array}{l}\text { Opportunity } \\
\text { cost(Ninan et al., } \\
2016)\end{array}$} & \\
\hline Value of time(TZS/Hour) & G3 & & \\
\hline \multicolumn{4}{|l|}{ Physical disservices $\left(\mathrm{C}_{3}\right)$} \\
\hline Physical damage caused by green spaces & & \multirow{6}{*}{$\begin{array}{l}\text { Averting } \\
\text { behavior Defra } \\
(2007)\end{array}$} & \\
\hline Property damage caused by green spaces & & & \\
\hline Current recovery cost if already fixed(TZS) & K4 & & \\
\hline Percentage of households affected by disservices & $\mathbf{C}$ & & \\
\hline Possible recovery cost if not fixed (TZS) & L4 & & $\mathbf{K} 4+\mathbf{L} 4+\mathrm{M} 4+(\mathbf{N} 4 \times \mathbf{O}$ \\
\hline $\begin{array}{l}\text { Expected current labour cost if labour force was or will be hired } \\
\text { (TZS) }\end{array}$ & M4 & & 4) \\
\hline $\begin{array}{l}\text { Time spent per week if household member was or will be in } \\
\text { charge (Hour) }\end{array}$ & $\mathbf{N 4}$ & \multirow{2}{*}{$\begin{array}{l}\text { Opportunity } \\
\text { Cost(Ninan et al., } \\
\text { 2016) }\end{array}$} & \\
\hline Value of time(TZS/hour) & 04 & & \\
\hline \multicolumn{4}{|l|}{ Social, economic and security disservices $\left(\mathrm{C}_{4}\right)$} \\
\hline Economic loss(TZS) & $\mathbf{P 4}$ & \multirow{6}{*}{$\begin{array}{l}\text { Averting } \\
\text { behavior } \\
(2007)\end{array}$} & \multirow{8}{*}{$\begin{array}{l}\text { P4+Q4+R4+S4+T4+ } \\
(\mathrm{U} 4 \times \mathbf{W} 4)\end{array}$} \\
\hline Property monetary loss (TZS) & Q4 & & \\
\hline Percentage of households affected by disservices & $\mathbf{C}$ & & \\
\hline The recovery cost if already fixed (TZS) & $\mathbf{R 4}$ & & \\
\hline The recovery cost if not fixed (TZS) & S4 & & \\
\hline $\begin{array}{l}\text { Expected current labour cost if labour force was or will be hired } \\
\text { (TZS) }\end{array}$ & T4 & & \\
\hline $\begin{array}{l}\text { Time spent per week if household member was or will be in } \\
\text { charge (Hour) }\end{array}$ & $\mathbf{U} 4$ & \multirow{2}{*}{$\begin{array}{l}\text { Opportunity } \\
\text { Cost(Ninan et al., } \\
\text { 2016) }\end{array}$} & \\
\hline Value of time(TZS/Hour) & W4 & & \\
\hline
\end{tabular}

\section{Results and Discussion}

\subsection{Ecosystem Disservices from Green Spaces in Residential Plots}

Despite the benefits accrued from home greeneries, it was reported by respondents that home greeneries had been attracting snakes and pests. Common pests included mosquitoes, rats, bats and cockroaches. Green spaces have 
been reported to cause repulsive smells due to mismanagement of yard waste and trees leaves. Furthermore, other home greeneries were reported to cause bad smells according to their intrinsic nature although smell is a subjective characteristic. Home greeneries have been reported to cause physical damages like damaging houses and pavements due to tree roots penetrating into foundations of buildings as well as harboring fungus, which taint wall paints. Other disservices were related to safety and security issues like theft and robbery. Respondents reported that green spaces were used to hide people with bad intentions. Forty-nine (49\%) of the respondents affected by disservices were found in Kawe followed by Mburahati, and Yombo Vituka. Makumbusho was least affected by disservices. This might be due to low coverage of greenery spaces in Mburahati, Yombo Vituka and Makumbusho compared to Kawe. In addition, home greeneries, suspected to be causing bad smell were reported by $45 \%$ and $48 \%$ of the respondents with green spaces in Mburahati and Kawe, respectively. This might be due to the vegetation species planted or inadequate management of yard waste in residential plots. Among other factors like cost and space availability at residential plots, ecosystem disservices from green spaces have been reported to discourage about $20 \%$ of the respondents to invest in green spaces in their residential plots.

\subsection{Economic Valuation of Ecosystem Disservices}

As reported previously, residential greeneries have been causing negative effects in the aesthetics, health, safety and security, physical, social and economic aspects. Survey data have shown that $35 \%$ of the respondents did not encounter the aforementioned disservices. Disservices which are aesthetic in nature were reported by the majority $(64.6 \%)$ of respondents followed by health $(20 \%)$ and physical structure disservices $(8 \%)$. The disservices related to social, economic and security affected $2.3 \%$ of the respondents.

Valuation of ecosystem disservices from home greeneries has revealed that a household can incur an average total cost of TZS 116,817 (USD 50) per year, which is about $5 \%$ of the annual household income. At the City level, the total cost of disservice is estimated to be about TZS 106 billion (USD 70 million) per annum. Economic cost of ecosystem disservices for households, which rely on single home greenery type showed fruit trees as the single home greenery type that has the highest value of ecosystem disservices per household per year (TZS 433,000(USD188)) followed by those with shade trees (TZS 124,000(USD 54)). It can be observed that the aesthetic disservice contributes the highest percentage (80.7\%) to average cost followed by health related disservices (11.6\%) (Figure 2). This observation defies the fact that in the first place, most of the households establish green space for enhancing aesthetic value of their premises thus suggesting that residents establish green spaces in their residential plots with low awareness on ecosystem disservices associated with types of green spaces they chose.

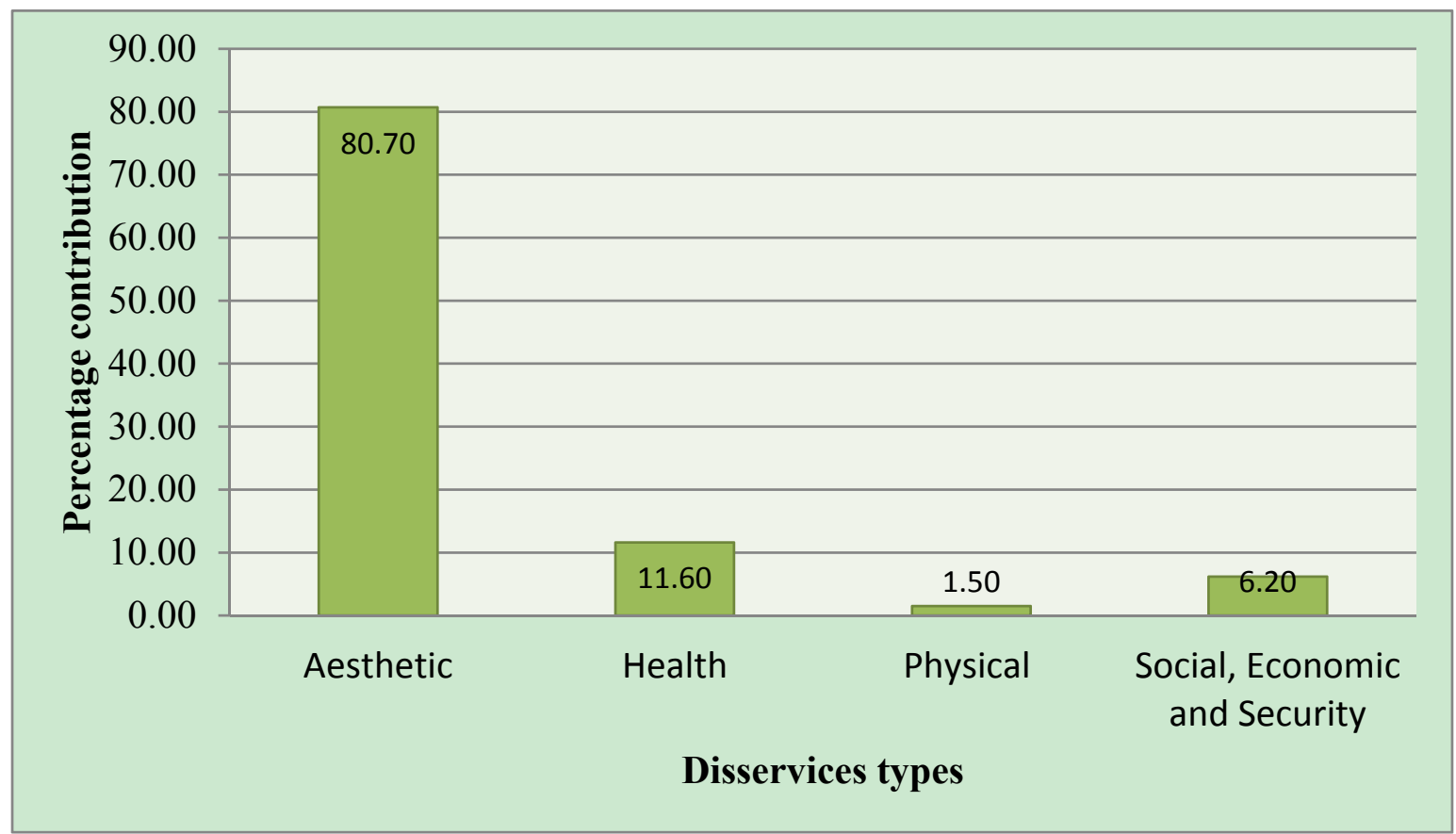

Figure 2. Contribution of ecosystem disservices to total economic value of green spaces 


\subsection{Aesthetics and Health based disservices}

The presence of home greenery has been a source of yard waste including leaf litter. Due to unreliable solid waste management systems in most of the case study areas, the rotten yard waste and leaf litter have been creating unhygienic conditions and are a source of flies and cockroaches as Bernardo (2008) and Etim et al. (2013) also reported. In addition, poorly selected species of vegetation and mismanaged residential green spaces harbour vectors of diseases such as mosquitoes, rats and flies. However, solid waste and mosquitoes were respectively the main aesthetic and health based disservices, which were reported by more than a quarter $(25 \%)$ of the respondents. Survey data showed that $25 \%$ of the households have been struggling with aesthetic disservices in terms of prevention and control. The dominant methods for prevention and control of aesthetic and health disservices included regular sweeping of solid waste, regular pruning of trees, spraying air fresheners, fumigation, use of rodenticide, burning, use of mosquito nets, burying of yard waste and pesticides application. These methods are imposing an economic burden to households in terms of materials, labour and opportunity cost of time to deal with the disservices. Households spend an average of 60,691 TZS (USD 26) per year on prevention and control of aesthetic and health disservices.

Despite of the deliberate efforts on prevention and control of health disservices, households in the studied settlements were found to suffer from malaria and other diseases like diarrhea, which are partly implicated to be due to mismanaged home greeneries as Ernstson et al. (2013) also reported. Diarrhea is largely caused by unhygienic conditions particularly inadequate waste management. The percentage of household suffering from various diseases suspected to be related to home greenery was $20 \%$. Dunn (2010) reported that some home greeneries can be a source of allergic reactions to household members, however, this was not reported during the survey exercise probably because awareness on allergic reactions caused by plants and food is generally low in developing countries Tanzania being no exception (Boye, 2012). In general, it was observed that on average respondents suffer from disservices related diseases between two and six times a year. The percentage of households who suffer episodically was $77.6 \%$ while those who suffer chronically was $22.4 \%$. In both aesthetics and health disservices related disease cases, Yombo Vituka was leading accounting for $90 \%$ and $22.5 \%$, respectively. This might be due to poor management of home greenery in residential plots especially in low lying areas. Twenty-five percent $(25 \%)$ of sick persons go for treatment to government dispensaries, which are located within their settlements. Others use traditional home-based treatment, health centre, private dispensary and the National Hospital. The reported means used for treatment have cost implications in terms of transport, treatment, opportunity cost of productive time to both patients and care takers. To treat diseases related to disservices, households are incurring an average cost of TZS 94,843 per year while at the City level, the annual cost is about TZS 21 billion (USD 8,997,420). The ward which was found to have the highest average cost per year is Kawe (TZS 129,880 (USD 56)) followed by Makumbusho (TZS 129,347 (USD 56)), Mburahati (TZS 60,141.5 (USD 26)) and lastly Yombo Vituka (TZS 55,604.01 (USD 24)). One-way Analysis of Variance (ANOVA) indicated that the difference in average cost is statistically significant $(p>0.05)$ for the four wards $\left(F_{(3,98)}=0.836, p=.477\right)$ implying that cost of treatment of ailments related to green space disservices are comparable regardless of the location.

\subsection{Physical Damage Disservices}

According to respondents, home greeneries are implicated for causing physical and property damages notably cracking of structures, damage of pavements and buildings by roots of trees, accidents and corrosion of roofing materials of buildings. Home greenery especially trees have been affecting structure through corrosion of roofs due to bird excrements and accumulation of rotten leaf litter. The percentage of respondents who have been facing these disservices in case study areas was only $8 \%$ suggesting that physical damage due to home greenery is not common in most of the settlements. Physical damages are experienced in Kawe and Yombo Vituka where the percentages of the respondents who reported to suffer from such disservices were $38.5 \%$ and $33.3 \%$, respectively. These settlements have highest home greenery space coverage compared to the other studied settlements. The percentages of respondents suffering from physical damages for other settlements were $15.4 \%$ for Makumbusho ward and $12.8 \%$ for Mburahati ward. These disservices are responsible for cost of recovery, labour and opportunity cost of time lost. The studied households have reported to incur an average cost of TZS 243,835 (USD 106) per year to remedy the situation, which translate to about TZS 21.4 billion (about USD 9.3 million) per year at the City level. The ward which leads in incurring average remedial cost per year is Kawe (TZS 578,939 (USD 252)) followed by Makumbusho (TZS 130,611.0 (USD 57)), Mburahati (TZS 108,614.5 (USD 47)) and Yombo Vituka (TZS 92,474.0 (USD 40)). One-way Analysis of Variance (ANOVA) indicated that differences in average cost are not statistically significant $(p>.05)$ for the four wards $\left(F_{(3,37)}=0.919, p=0.441\right)$ thus implying that the cost incurred by households to remedy for physical damage related disservices is comparable regardless of the location. 


\subsection{Social, Economic and Security Disservices}

Home greeneries especially trees and hedges have been used by people with bad intentions at night-times thus compromising safety and security of households. Moreover, green spaces attract snakes especially during hot seasons. Snakes especially cobras seek refuge in cooler places inside homes during hot weather. The proportion of respondents in the studied areas who experience social, economic and security disservices was $2 \%$. Respondents of Yombo Vituka and Mburahati were affected most (more than 12\%) by social, economic and security disservices put together. Kawe settlement respondents reported that theft was the only security disservice they experience. These disservices have cost implications in terms of property loss, monetary loss, recovery cost, labour cost and opportunity cost of time. Households facing these disservices incur an average cost of TZS 741,061 (USD 322) per year and about TZS 19.1 billion (about USD 8.3 million) is lost due to social, economic and security related disservices from green spaces at the City level. Kawe settlement recorded the highest average cost of disservices (TZS 6,600,000 (USD 2870) per year). The disservice costs for other wards were TZS 436,593 (USD 190) per year for Makumbusho, TZS 117,000 (USD 51) per year for Mburahati and TZS 124,826 (USD 54) per year for Yombo Vituka. One-way Analysis of Variance (ANOVA) results indicated that the difference in average monetary cost due to social, economic and security disservices for the four wards $\left(F_{(3,25)}=151.8, p=3.34 * 10^{-5}\right)$ is statistically significant at $p<0.05$ suggesting that costs incurred by households in terms of social, economic and security disservices considerably differ amongst the studied areas. According to Tukey's honestly significant difference (HSD) post hoc test, the significant differences were observed between Kawe and Makumbusho and, Yombo Vituka and Mburahati. This might be due to the presence of many rich people in Kawe settlement as reflected by the highest average income (TZS 657,533 (USD 284) per month), which consequently tends to attract thieves.

\section{Conclusion and Recommendations}

Misuse, mismanagement and poor choice of green spaces in residential plots in Dar es Salaam City were implicated to cause negative effects (disservices) to health, physical, economic, safety and security aspects. Despite these challenges in developing and managing residential green spaces, households make deliberate efforts in creating and maintaining green spaces for maximizing their benefits. There is a need to raise awareness and enhance the capacity of departments responsible for environmental management to enable them recognize the value of green spaces and integrate aesthetic factors into their planning and budgeting. The departments should also be responsible for managing tree, grass and flower nurseries. Based on green space ecosystem disservices contributions in household expenditures, the study recommends that nursery owners need to be advised in selecting the right type of vegetation species to be grown in order to enhance the benefits of ecosystem services. Concerted efforts should be made to create awareness to City residents through ward environmental and health officers on appropriate ways of establishing and managing green spaces for minimizing ecosystem disservices and maximizing their benefits.

\section{Acknowledgements}

We would like to express our heartfelt thanks to all the people who contributed in different ways to make this publication possible. First, we thank the Almighty God for his grace, protection and ability he gave us to do and complete this publication. Second, we are honored to extend our sincere gratitude to Prof. Robert Kiunsi, and Dr. Patrick O'Farrell for their involvement during manuscript preparation. Exclusively, I thank DAAD and Ardhi University for financial support.

\section{References}

Boye, J. I. (2012). Food allergies in developing and emerging economies: need for comprehensive data on prevalence rates. Clin Transl Allergy. https://doi.org/10.1186/2045-7022-2-25

Campagne, C. S., Roche, P. K., Salles, J. M., Campagne, C. S., Roche, P. K., \& Looking, J. M. S. (2018). Looking into Pandora's Box: ecosystem disservices assessment and correlations with ecosystem services HAL Id: hal01945369 Looking into Pandora's Box: Ecosystem disservices assessment and correlations with ecosystem services. https://doi.org/10.1016/j.ecoser.2018.02.005

Cariñanos, P., Calaza-martínez, P., \& Brien, L. O. (2017). The Cost of Greening: Disservices of Urban Trees Chapter 9 The Cost of Greening: Disservices of Urban Trees. https://doi.org/10.1007/978-3-319-50280-9

Defra, U. (2007). An introductory guide to valuing ecosystem services: Defra publications. Retrieved from http://www.defra.gov.uk/publications/2011/03/28/pb12852-ecosystem-services

Dobbs, C., Escobedo, F. J., Clerici, N., Barrera, F. De, \& Eleuterio, A. A. (2019). Urban ecosystem Services in Latin America: mismatch between global concepts and regional realities? Urban ecosystem Services in Latin America: mismatch between global concepts and regional realities? https://doi.org/10.1007/s11252-018- 
0805-3

Dunn, R. R. (2010). Global mapping of ecosystem disservices: the unspoken reality that nature sometimes kills us. Biotropica, 42(5), 555-557. https://doi.org/10.1111/j.1744-7429.2010.00698.x

Ernstson, H., \& Sörlin, S. (2013). Ecosystem services as technology of globalization: On articulating values in urban nature. Ecological economics, 86, 274-284. https://doi.org/10.1016/j.ecolecon.2012.09.012

Kibassa, D., \& Shemdoe, R. (2016). Land Cover Change in Urban Morphological Types of Dar es Salaam and Its Implication for Green Structures and Ecosystem Services. https://oi.org/10.15341/mese(23332581)/03.02.2016/005

Lupala, J., \& Kiunsi, R. (2011). Dar es Salaam city, 50 years to come: conceptual considerations. Paper presented at the Unpublished working workshop paper.

Lyytim, J. (2019). Disservices of urban trees. (April 2017). https://doi.org/10.4324/9781315627106.ch12

Ninan, K., \& Kontoleon, A. (2016). Valuing forest ecosystem services and disservices-Case study of a protected area in India. Ecosystem services, 20, 1-14. https://doi.org/10.1016/j.ecoser.2016.05.001

Oro, I. D. E. L. T., Ibbons, R. R. R., \& Elini, S. L. P. (2012). The little things that run the world revisited: A review of ant-mediated ecosystem services and disservices (Hymenoptera: Formicidae) The little things that run the world revisited: a review of ant-mediated ecosystem services and disservices (Hymenoptera: Formicidae).

Pagiola, S., Von Ritter, K., \& Bishop, J. (2004). Assessing the economic value of ecosystem conservation. World Bank, Environment Department.

Speak, A., Escobedo, F. J., Russo, A., \& Zerbe, S. (2018). An ecosystem service-disservice ratio: Using composite indicators to assess the net bene fits of urban trees. Ecological Indicators, 95(July), 544-553. https://doi.org/10.1016/j.ecolind.2018.07.048

Vaz, A. S., Kueffer, C., Kull, C. A., Richardson, D. M., Vicente, J. R., Ingolf, K., \& Honrado, P. (2017). Integrating ecosystem services and disservices: insights from plant invasions. https://doi.org/10.1016/j.ecoser.2016.11.017

Wang, H., Qureshi, S., Knapp, S., Ross, C., \& Hubacek, K. (2015). A basic assessment of residential plant diversity and its ecosystem services and disservices in Beijing, China. Applied Geography, 64, 121-131. https://doi.org/10.1016/j.apgeog.2015.08.006

\section{Copyrights}

Copyright for this article is retained by the author(s), with first publication rights granted to the journal.

This is an open-access article distributed under the terms and conditions of the Creative Commons Attribution license (http://creativecommons.org/licenses/by/4.0/). 